\title{
A család- és gyermekjóléti szolgálatok szerepe a társadalmi mobilitás elősegítésében - a munkatársak nézőpontjából ${ }^{1}$
}

\author{
KOPASZ MARIANNA² - HUSZ ILDIKÓ ${ }^{3}$
}

\begin{abstract}
ABSZTRAKT
A tanulmány arra keres választ, hogy miként vélekednek a hazai családsegítók a szegénység enyhítésével összefüggő szerepükröl, valamint arról, hogy mennyire adottak, vagy épp ütköznek korlátokba ennek lehetôségei. Az elemzés alapjául egy olyan adatfelvétel szolgált, amelyben 600 gyermekjóléti és családsegítố szolgálatnál dolgozó munkatársat kérdeztünk meg 2018 és 2019 fordulóján. Eredményeink szerint konszenzus van a szakemberek között abban, hogy a szociális munkának szerepe van a családok szegénységének enyhítésében. Adataink ugyanakkor azt sugallják, hogy feszültség van a szociális munkások szakmai szerepfelfogása és a szerep betöltésének lehetőségei (vagy talán még inkább az arra való képtelenség) között. Elemzéseink szerint a szociális munkások szegénységgel összefüggő szerepfelfogása nem mutat eltérést a szokásos szociodemográfiai jellemzőik mentén. A tanulmány egyik fontos eredménye ugyanakkor, hogy a szegénységgel kapcsolatos szerep betöltésének lehetöségeiről eltéröen vélekednek a szociális munkások, attól függően, hogy milyen társadalmi összetételü az ellátási terület, ahol a tevékenységüket végzik. A hátrányos helyzetü településeken, ahol sok szegény vagy roma család él, a szakemberek kevésbé látják úgy, hogy a szegénység elleni küzdelem belefér a munkájukba. Így a szegény családok meglévő hátrányait tovább súlyosbítja, hogy az ellátórendszer épp azokon a helyeken képes a legkevésbé felvállalni a szegénység mérséklésével kapcsolatos szerepet, ahol erre a legnagyobb szükség lenne.
\end{abstract}

KULCSSZAVAK: szegénység csökkentése; szerepfelfogás; szociális munkások; gyermekjóléti és családsegítő szolgálatok, Magyarország

\footnotetext{
${ }^{1}$ A kutatás az EFOP-1.4.1-15 projekt (Integrált gyermekprogramok szakmai támogatása) és a Társadalomtudományi Kutatóközpont Mobilitás Kutatási Centrum (MTA Kiválósági Együttműködési Program) támogatásával készült.

2 Társadalomtudományi Kutatóközpont Politikatudományi Intézet; kopasz.marianna@tk.mta.hu

${ }^{3}$ Társadalomtudományi Kutatóközpont Gyerekesély-kutató Csoport; BCE Szociológia és Társadalompolitika Tanszék; husz.ildiko@tk.mta.hu
} 


\section{TEMATIKUS TANULMÁNYOK - Társadalmi mobilitás és segítői tevékenység}

\section{ABSTRACT}

\section{The role of family and child welfare services in promoting social mobility - from a staff perspective}

The study aims to seek answers to the following questions: how do Hungarian child and family social workers perceive their role in addressing poverty, the potential they have to tackle poverty, and the barriers they face when filling this role. The analyses are based on a survey of 600 social workers at child and family services conducted at the turn of 2018 and 2019. Our findings indicate a consensus among professionals that social work does have a role in addressing poverty. At the same time, the data suggest a tension between the role perception of social workers and the potential (or rather the lack of potential) for filling this role. There is no difference in the role perceptions of professionals according to their individual level sociodemographic variables. However, an important finding of the study is that perceptions of the possibilities for alleviating poverty depend on the socio-demographic characteristics of the area where they carry out their activity. In settlements with high shares of poor or Roma populations, social workers are less likely to think that addressing poverty can be part of their professional daily routine. Thus, the situation of poor families living in these settlements is exacerbated by the fact that it is these places where the child and family service system is the least capable of taking on the role of tackling poverty.

KEYWORDS: addressing poverty; perception of role; social workers; child and family social services, Hungary

\section{Bevezetés}

Nem magától értetődő, hogy a szociális munkának van-e és milyen szerepe lehet a szegénység leküzdésében és a társadalmi mobilitás növelésében. Szegénységen itt nem pusztán az alacsony vagy elégtelen jövedelmet értjük, hanem a különféle gazdasági, kulturális és közösségi erőforrások hiányát. Azon erőforrásokét, amelyek birtoklása szükséges lenne a szegénységből való kilépéshez és ezáltal a társadalmi mobilitáshoz, mind intra-, mind intergenerációs viszonylatban.

A szegénység és kirekesztettség problémájával a szociális szakmán belül a leggyakrabban a család- és gyermekjóléti szolgálatok találkoznak, így náluk vetődik fel a legélesebben a szerepükre vonatkozó dilemma. Egyfelől a statisztikák azt mutatják, hogy a szolgálatok által észlelt fő problémák minden ötödik esetben a család megélhetési nehézségével kapcsolatosak, de a családi konfliktusok, az életvezetési, gyermeknevelési gondok is gyakran összefüggésbe hozhatók a szegénységgel (KSH 2016). A megélhetési és lakhatási nehézségek növekvő dominanciája a szolgálatok munkatársai szerint már a 2000-es évektől észlelhető, a gazdasági válság ezt csak tovább fokozta (Rácz 2015). Ugyanakkor a szociális munkásnak nincs ráhatása a szegénység olyan strukturális okaira, mint a globális gazdaság munkaerőpiacának múködési zavarai vagy a jóléti állam újraelosztási problémái. Akármennyire is befo- 


\section{TEMATIKUS TANULMÁNYOK - Társadalmi mobilitás és segítői tevékenység}

lyásolja tehát a munkájuk eredményességét a kliensek társadalmi státusa, lehetőségeik ennek megváltoztatására korlátozottak.

Ebben a tanulmányban azt mutatjuk be, hogy hogyan gondolkodnak erről a dilemmáról a magyar családsegítő szakma képviselői. Az írás első részében a nemzetközi diskurzust tekintjük át abból a szempontból, hogy milyen lehetséges szerepek kínálkoznak a szociális szakemberek számára a szegénység elleni küzdelemben. A második részben egy kérdőíves felmérésnek a témával kapcsolatos eredményeit ismertetjük. A felvétel a család- és gyermekjóléti szolgálatoknál dolgozók körében készült.

\section{A szociális munka lehetséges szerepei a szegénység csökkentésében - Szakirodalmi áttekintés}

Mielőtt a lehetséges szerepeket bemutatnánk, előtte ki kell térnünk a szegénység mint probléma társadalmi konstrukciójára. Ahogy arra a gyermekvédelem kapcsán Szöllősi (2003) is rámutatott, az, hogy mit tekint problémának a szociális szakma, mi képezi a szociális munka tárgyát, nem független attól, hogy miként konstruálódik a probléma. Abból indulunk ki, hogy a szegénység koncepciója nem neutrális, hanem normatív és ideologikus konstrukció (Mestrum 2011, Schittecat et al. 2014). Ennek megfelelően a különböző történelmi időszakokban uralkodó társadalmi, gazdasági és politikai problémákkal összhangban változik a szegénység arca és változnak a leküzdését célzó intézkedések is. Az arról szóló diskurzusban, hogy mi minősül beavatkozást igénylő problémának, szerepet játszanak a szociális szakma szempontjai is, de a konstrukció folyamatának kulcsszereplője mégis az állam, amely a közpolitikai folyamat során bizonyos helyzeteket közüggyé nyilvánít és fellép azok kezelése érdekében (Szöllősi 2003).

Az elmúlt két évtizedben a jóléti rezsimek átalakulása kapcsán a szegénység mint probléma konstrukciójában olyan változásoknak lehetünk tanúi, amelyek minden bizonnyal befolyással vannak arra, hogy a szociális munkások hogyan gondolkodnak a szegénységről és saját szerepükről ezzel kapcsolatban ${ }^{4}$. Az európai jóléti államok fókusza a jövedelembiztonság megteremtése és a készpénzes juttatások felől a humántőke beruházás stratégiái felé fordult (Cantillon 2011). Ez az elmozdulás a társadalmi beruházás paradigma felé azt vonja maga után, hogy a kormányok az élet kihívásaival való szembenézésre „készítik fel” az állampolgárokat ahelyett, hogy azoknak a következményeit „állítanák helyre” (Mestrum 2013, idézi Schiettecat et al. 2014).

A társadalmi beruházás paradigmában a gyerekek és a gyermekkor a sikeres beruházási stratégia kulcsa. Mivel a korai életkorban való szegénységellenes beavatko-

${ }^{4}$ E változások alábbi rövid összefoglalásában Schiettecat et al. (2014) gondolatmenetét követjük. 


\section{TEMATIKUS TANULMÁNYOK - Társadalmi mobilitás és segítői tevékenység}

zások a leghatásosabbak és leginkább költséghatékonyak (Heckman 2006) a szociális munka mint szociálpolitikai eszköz fókusza egyre inkább a gyermeket középpontba állító családsegítés. A gyermek mint a jövő állampolgára és munkavállalója lesz a beavatkozás központi tárgya (szemben a szülővel) (Schiettecat et al. 2014).

A koragyermekkori oktatásra és gondozásra (ECEC) a különböző nemzetközi szervezetek már jó ideje úgy tekintenek, mint olyan eszközre, amely legalább bizonyos mértékig kompenzálni képes az otthonról hozott hátrányokat. Ugyanakkor egyes kutatók arra figyelmeztetnek, hogy kevés a rendelkezésre álló empirikus evidencia arra vonatkozóan, hogy az ECEC képes az esélyek kiegyenlítésére (Staab 2010). Mások azzal kapcsolatosan adnak hangot aggályaiknak, hogy a szegénység problémáját pusztán iskolázottsági problémaként keretezzük. Az a feltételezés, hogy a koragyermekkori ellátások egyenlősége csökkentené a társadalmi egyenlőtlenségeket, nem csak empirikusan támadható, hanem amiatt a mögöttes feltételezés miatt is, mely szerint a jövőbeli iskolai és azt követő eredményeket elsődlegesen az egyéni erőfeszítések és a tehetség befolyásolnák (Morabito et al. 2013).

Az 1990-es években a „szülőség” (parenting) fogalma bekerült az európai közbeszédbe és családpolitikai diskurzusba, és szemben a partnerkapcsolatisággal (partnering) közüggyé vált, azaz legitim terepe lett a családok privát széférájába való állami beavatkozásnak (Hall et al. 2010). Ez a 'szülőség irányába tett fordulat' (Bermaoui et al. 2012: 1) a szegénységről folyó diskurzus eltolódását jelzi a jövedelembiztonság felől a szülői támogató szerepek megerősítésének irányába. Az ennek alapjául szolgáló logika szerint a szegénység nem annyira, mint az erőforrások és a hatalom újraelosztásának kérdése jelenik meg, hanem mint a gyermekek és szülők egyéni iskolai kompetenciáinak hiánya, így a fókusz egyre inkább az egyéni és a szülői felelősség irányába terelődik (Clarke 2006, Popkewitz 2003). ${ }^{5}$

A szülői készségek preventív célú támogatása ugyanakkor több okból is kritizálható. Egyes szerzők bírálják a jó szülőségnek azt a felfogását, mely szerint az pusztán egy olyan feladat vagy technika volna, amelyik a gyermek fejlődésében és felnőttkorában a kívánatos kimenetet biztosítja (Clarke 2006, Gillies 2008). Ebben a megközelítésben a jó szülőségre mint a gyermek társadalmi mobilitásának letéteményesére tekinthetünk (Schiettecat et al. 2014). Mindeközben gyakran nem veszünk tudomást olyan szélesebb strukturális folyamatokról, amelyek a szegénységet és a társadalmi egyenlőtlenségeket eredményezik (Axford 2010).

\footnotetext{
${ }^{5}$ Nem csak a szociális munka függ attól, hogy miként konstruálunk meg egy adott problémát, de a szociális munka is befolyásolja a probléma konstrukcióját (Vandenbroeck et al. 2010, Schiettecat 2014). Ha például a szegénységet mint a szülők és gyermekek hiányos iskolázottságát észleljük, akkor a megoldást a gyermek és család számára nyújtott szociális munka jelenti. Amikor azonban ennek keretében a nélkülözésben élők számára szülőket támogató programot kínálnak, minden alkalom megerősíti azt a képzetet, hogy az ilyen helyzetben lévő szülőknek speciális oktatási szükségleteik vannak; azaz szegény szülőnek lenni egyenlő a rossz szülőséggel. Ez azt is implikálja továbbá, hogy a szülőség szakértők által tanítható készségek összességeként fogható fel, miközben megfeledkezünk az erőforrások és hatalom hiányából fakadó lehetséges korlátokról (Lister 2004).
} 


\section{TEMATIKUS TANULMÁNYOK - Társadalmi mobilitás és segítői tevékenység}

Azt a mai napig vita övezi, hogy mi következik mindebből a szociális szakma, ezen belül a család- és gyermekjólét területén dolgozók szerepére nézve a szegénység elleni küzdelemben. A kérdést feltehetjük fordított nézőpontból is, mint ahogyan azt Dowling (1999) tette, amikor felvetette, hogy a szegényeknek szükségük van-e egyáltalán a szociális munkára. Az egyik lehetséges válasz szerint nincs szükségük, mivel a szociális munkánál sokkal hatékonyabb a szélesebb politikai és strukturális problémák megoldása. Ezzel szemben a pragmatikus álláspont arra az érvre hivatkozik, hogy még ha az anyagi és praktikus segítség, amit a szociális munkás nyújthat, mindössze csak átmeneti is, a segítségért folyamodó szemszögéből nézve ez is jobb a semminél (Dowling 1999).

A téma különösen a gyermekjólét területén váltott ki vitákat. Egyesek (Duva Metzger 2010) szerint a gyermekjólét szerepfelfogásában ma is megmutatkozik az a tradíció, mely szerint a feladata a gyerekek biztonságának biztosítása és a veszélyektől való védelme, nem pedig a szegénység enyhítése. Arra a tágabb kontextusra ugyanakkor kevésbé van nyitottság, hogy a gyerekekkel kapcsolatos ártalmakban a szegénység milyen szerepet játszik. Ezt a hiányosságot Duva és Metzger (2010) a gyermekjólét rendszerszintű jelenségének tartja.

Mások további érveket hoztak fel arra, hogy miért szükséges és kívánatos, hogy a szociális szakma és ezen belül a gyermekjólét szerepet vállaljon a szegénység elleni küzdelemben. Az egyik érvrendszer szerint a szegénység léte a társadalmi igazságosság kérdéskörébe tartozik, és mint ilyen, kezelése központi jelentőségű kell, hogy legyen a szociális munka számára (Cartan et al. 2018). Egy másik nézőpont annak jelentőségét hangsúlyozza, hogy a gyermekjóléti rendszer feladatának tekinti-e a (gyermek)szegénység megszüntetését, mint a gyermekjólét biztosításának eszközét vagy sem. Ha ugyanis ez általánosan elfogadott cél lenne, akkor ez a személet átalakítaná a szociális munkások mindennapi gyakorlatát is: ehhez igazítanák az eszközöket, így a kivizsgálás és intervenció helyett a prevencióra és a jövőorientált megoldásokra helyeződne a hangsúly (Lindsey 2003, Martin - Citrin 2014).

A fenti tanulmányok az elvi megfontolásokról szólnak. Arról azonban sokkal kevesebb tudásunk van, hogy maguk a család- és gyermekjólét területén dolgozó szociális szakemberek hogyan gondolkodnak a saját szerepükről a szegénység leküzdésében és a társadalmi mobilitás elősegítésében. Carlson (2017) harminc közép-nyugat-amerikai gyermekjóléti munkatárssal készített interjú alapján azt találta, hogy többségük kételkedik abban, hogy bármit is el tudna érni a szegénység kezelésében. Egyesek nem is gondolták feladatuknak a szegénység elleni küzdelmet, azt hangsúlyozva, hogy munkájuk elsődleges célja nem ez, hanem a gyermek biztonságának biztosítása. Mások ugyan nem hárították maguktól a szerepet, de úgy vélték, hogy számos rendszerszintű tényező korlátozza a szociális munkásokat abban, hogy képesek legyenek küzdeni a szegénység ellen. Olyan külső nehezítő erőket említettek, mint az elégtelen állami és önkormányzati politikákat, amelyek túlságosan is szűkös erőforrásokat biztosítanak a problémák kezelésére, vagy a nem kellően átgondolt 


\section{TEMATIKUS TANULMÁNYOK - Társadalmi mobilitás és segítői tevékenység}

szabályozásokat, valamint a nagy adminisztratív leterheltséget. Emellett néhányan megemlítették a kliens családok normáinak és elvárásainak szerepét is, mint amelyek nehezítik az eredményes szociális munkát. Akik feladatuknak tekintették a szegénységgel való foglalkozást, ők saját szerepüket gyakran úgy határozták meg, mint „erőforrás-brókereket”, akik a klienseket a céljaik eléréséhez szükséges erőforrások felkutatásával és közvetítésével segítik. Mások az érdekképviseleti szerepet (advocacy) hangsúlyozták és a kliensek támogatását abban, hogy hozzájussanak az erőforrásokhoz. Ugyanakkor elismerték, hogy ez csak rövidtávú megoldást jelent, míg hosszútávon a jóléti programok által nyújtott lehetőségek nem elegendőek.

A továbbiakban azzal foglalkozunk, hogy mit gondolnak mindezekről a magyar család- és gyermekjóléti szolgálatok munkatársai. Az elemzéshez felhasznált adatbázis nem alkalmas arra, hogy a témát sokféle szempontból és kellő mélységben körüljárjuk, ezért inkább csak szempontokat vetünk fel a kérdés további vizsgálatához.

\section{Kutatási kérdések, adatok és módszer}

Empirikus vizsgálatunkban az alábbi kérdésekre keresünk választ. i) Hogyan vélekednek a hazai család- és gyermekjóléti szolgálatok munkatársai arról, hogy van-e szerepe a szociális munkásoknak a szegénység enyhítésében? És ha igen, ii) mennyire adottak ennek a feltételei, illetőleg milyen tényezők akadályozzák e szerep betöltését? iii) Milyen egyéni és nem egyéni szintű jellemzők befolyásolják a szociális munkások szegénységgel kapcsolatos szerepfelfogását, illetve az annak lehetőségeiről és korlátairól való vélekedéseiket?

Az elemzéshez egy kérdőíves felvétel ${ }^{6}$ adatait használtuk, amelyet a család- és gyermekjóléti szolgálatok munkatársai körében kérdeztek le 2018. november és 2019. február között. Az adatfelvétel elsődleges célja a szolgálatok munkakörülményeinek felmérése volt, emellett tartalmazott egy kérdésblokkot arra vonatkozóan is, hogy mit gondolnak a megkérdezettek a szociális munkások szerepéről a szegénység leküzdésében. A mintaválasztáskor szempont volt, hogy a minta regionálisan reprezentálja a család- és gyermekjóléti szolgálatokat, továbbá hogy az egyszemélyes szolgálatok megfelelő arányban kerüljenek a mintába. A felmérés során összesen 178 településen és a főváros 9 kerületében, 600 fős mintán történt a számítógéppel támogatott személyes megkérdezés (CAPI).

A szociális munkások szegénységgel kapcsolatos szerepére vonatkozóan a kérdőív hét kérdést tartalmazott. ${ }^{7}$ Az ezekben megfogalmazott állításokkal való egyetértést minden esetben négyfokú skálán mértük. A harmadik kutatási kérdésünkhöz,

\footnotetext{
${ }^{6}$ A felmérés címe: A család- és gyermekjóléti szolgálatoknál dolgozók helyzete (témaszám: EFOP 2018-004, kutatásvezető: Husz Ildikó).

${ }^{7}$ A kérdőív idevágó kérdéseinek összeállítása során Carlson (2017) fentebb bemutatott kutatásának eredményeire is építettünk.
} 


\section{TEMATIKUS TANULMÁNYOK - Társadalmi mobilitás és segítői tevékenység}

amely a válaszok mögötti, szociodemográfiai és települési tényezők szerinti eltéréseket vizsgálta, az alábbi változókat használtuk: a megkérdezett neme, életkora, munkatapasztalata, a diploma területe (szociális munka/szociálpolitika/szociológia vagy egyéb), valamint hogy gyerekkorában érintett volt-e olyan problémával, ami a mostani klienseire jellemző; a munkavégzés helyének településtípusa, a településen észlelt szegénység, a település szociális szolgáltatásokkal való ellátottsága. A kutatási kérdések megválaszolásához egy- és kétváltozós elemzést, egyszerú kereszttáblákat használtunk.

\section{Eredmények: a családsegítők szegénységgel kapcsolatos szerepfelfogása, a szerep betöltésének lehetőségei, illetve korlátai}

\section{SZEREPFELFOGÁS}

A szociális munkás potenciális szerepére vonatkozóan három állítással kapcsolatban kértük a válaszadók véleményét (lásd 1. táblázat).

A családsegítők döntő többsége $(71,1 \%)$ inkább vagy teljes mértékben egyetértett azzal az állítással, hogy a szociális munkásoknak van szerepük a családok szegénységének enyhítésében. Ezzel összefüggésben arról is kérdeztük őket, egyetértenek-e azzal, hogy a szegénység elleni küzdelem és a családok segítése az alapvető szükségleteik előteremtésében két különböző szerep. A válaszadók 72,9\%-a ezt az állítást is helyeselte. Azt várhatnánk, hogy a fenti két kérdésre adott válaszok öszszefüggenek, vagyis azok, akik szerint a szociális munkának nincs a szegénységgel kapcsolatos szerepe, nagyobb arányban látják úgy, hogy a családok segítése és a szegénység elleni küzdelem egymástól eltérő szerepek. Ezt a várakozásunkat azonban nem támasztják alá a két változó közötti összefüggésre vonatkozó statisztikák.

Azt is megnéztük, hogy a szociális munka szerepéről vallott nézetek hogyan alakulnak a különböző egyéni, illetve települési szintű változók függvényében. Mivel szignifikáns összefüggést a két idevágó kérdés közül csak az első esetében mutattunk ki, a továbbiakban csak az azzal kapcsolatos eredményeket ismertetjük.

Előzetesen az volt a várakozásunk, hogy a szerepfelfogásban a közös szakmai értékek és elvek tükröződnek, így nagyfokú homogenitást vártunk a válaszadók szociodemográfiai változói mentén. Egyszerű, kétváltozós eredményeink alátámasztották ezt, azaz a szegénységgel kapcsolatos szakmai szerepfelfogás nem függ öszsze egyetlen általunk vizsgált egyéni szociodemográfiai változóval sem, beleértve a válaszadó nemét, életkorát, munkatapasztalatát, diplomájának típusát. A szerepfelfogást az sem befolyásolja, hogy a megkérdezett a pályáját a rendszerváltást megelőzően kezdte-e, vagy pedig azt követően.

Ugyanakkor egyértelmű összefüggés rajzolódik ki a válaszadók személyes érintettsége és a szerepfelfogás között (lásd 2. táblázat). Azok, akik korábban sa- 


\section{TEMATIKUS TANULMÁNYOK - Társadalmi mobilitás és segítői tevékenység}

ját tapasztalatot szereztek a szegénységgel, vagy más olyan szociális problémával, amellyel munkájuk során találkoznak, lényegesen nagyobb arányban vallják, hogy a szociális munkásoknak szerepe a családok szegénységének enyhítése, mint azok, akiknek nem volt részük ilyenben (77\%, szemben a 68,1\%-kal).

A települési szintű változók és a szerepfelfogás kapcsolatát többféleképpen is vizsgáltuk: objektív és szubjektív, vagyis a kérdezett észlelésén alapuló változókat is használtunk. Azt találtuk, hogy a településtípus szignifikánsan (0,1-es szignifikanciaszinten) összefügg a szociális munka szerepét illető vélekedésekkel (lásd 3. táblázat). Eltérés a falvakban dolgozó családsegítők és a többiek között (városiak és fóvárosiak) mutatkozik: míg a falvakban dolgozóknak 65,7\%-a ért egyet azzal, hogy a szakmának szerepe van a családok szegénységének enyhítésében, addig a városiaknak és a budapestieknek szignifikánsan nagyobb, 74,3, illetve 73,2\%-a.

A családsegítők ellátási területén észlelt társadalmi összetétel mérésére a kérdőívben több állítás szerepelt. Ezek mindegyike egy-egy társadalmi csoportra vonatkozott, és azt tudakolta, hogy a válaszadók egyetértenek-e azzal, hogy az ellátási területükön sok jól szituált, alacsony jövedelmű, súlyosan szegény, illetve roma család él. Szignifikáns kapcsolatot (0,05-ös szignifikanciaszinten) egyedül a jól szituált családok előfordulásával összefüggésben mutattunk ki. E szerint azok a válaszadók, akik az ellátási területükön sok jól szituált családról számolnak be, inkább hajlanak rá, hogy szerepüknek tekintsék a szegénység enyhítését, mint azok, akik ettől eltérő társadalmi környezetben dolgoznak (lásd 4. táblázat). Ugyanakkor úgy tűnik, nincs statisztikailag szignifikáns összegfüggés sem a mélyszegény, sem pedig a roma családok nagyszámú jelenléte és a szociális munkások szakmai szerepfelfogása között. Vagyis eredményeink szerint a szegénységgel kapcsolatos szakmai szerep szempontjából egyedül annak van jelentősége, hogy a környék kifejezetten jól szituált-e, vagy sem. Ha igen, vagyis ha a szegénység inkább kivételes, mint általános jellemzője az ellátási területnek, akkor a szociális munkások jobban hajlanak arra, hogy szerepüknek érezzék a családok szegénységének enyhítését.

A szerepfelfogással összefüggésben vizsgáltuk, továbbá azzal az állítással való egyetértést is, mely szerint „a szociális munkásnak nincs joga, hogy normákat közvetítsen a szegény családok felé". Ennek kapcsán erős konszenzus mutatkozott a szakmán belül: a válaszadók 71,5\%-a volt azon az állásponton, hogy legitim az ilyen fajta beavatkozás a szegény családok életébe (vagyis az állítással való egyet nem értését fejezte ki) (lásd 1. táblázat).

Úgy tűnik, egyetlen szokásosan vizsgált szociodemográfiai ismérvnek sincs hatása annak megítélésére, hogy joga van-e a szociális munkásnak a szegény családok felé normákat közvetíteni. A segítő szakember személyes érintettsége (saját gyermekkori tapasztalata) viszont hatással lehet rá. Azok a szakemberek, akik gyerekkorukban maguk is szembenéztek szociális problémákkal, szignifikánsan nagyobb arányban támogatják, hogy a szociális munkásnak joga van normákat közvetíteni a családok felé (lásd 5. táblázat). 


\section{TEMATIKUS TANULMÁNYOK - Társadalmi mobilitás és segítői tevékenység}

Nincs különbség a különböző típusú településeken dolgozó szociális munkások között abban, hogy mit gondolnak a szakmabeliek normák közvetítéséhez való jogáról. A szociális munkások által észlelt helyi társadalmi összetétel hatása is csak egyetlen változó esetében bizonyult szignifikánsnak. Eszerint, ahol kevés a súlyos szegénységben élő család, ott inkább formálnak jogot a szakemberek a normák közvetítésére (lásd 6. táblázat).

1. táblázat. A szociális munkás szegénységgel kapcsolatos szerepére, eszközeire és akadályaira vonatkozó állításokkal való egyetértés (\%)

\begin{tabular}{|c|c|c|c|c|c|}
\hline & $\begin{array}{l}\text { Egyáltalán } \\
\text { nem }\end{array}$ & $\begin{array}{c}\text { Inkább } \\
\text { nem }\end{array}$ & Inkább & Teljesen & $\mathrm{N}$ \\
\hline \multicolumn{6}{|l|}{ Szerepfelfogás } \\
\hline $\begin{array}{l}\text { A szociális munkásnak van szerepe a } \\
\text { családok szegénységének enyhítésében. }\end{array}$ & 4,5 & 24,4 & 52,2 & 18,9 & 598 \\
\hline $\begin{array}{l}\text { A szegénység leküzdése és a családok } \\
\text { segítése az alapvető szükségleteik elő- } \\
\text { teremtésében két különböző szerep. }\end{array}$ & 4,8 & 22,3 & 48,1 & 24,8 & 588 \\
\hline $\begin{array}{l}\text { A szociális munkásnak nincs joga, hogy } \\
\text { normákat közvetítsen a szegény csalá- } \\
\text { dok felé. }\end{array}$ & 34,2 & 37,3 & 21,9 & 6,6 & 590 \\
\hline \multicolumn{6}{|l|}{ Lehetőségek, eszközök } \\
\hline $\begin{array}{l}\text { A szociális munkásnak megvannak az } \\
\text { eszközei arra, hogy a családok szegény- } \\
\text { ség elleni küzdelmét segítse. }\end{array}$ & 16,1 & 37,5 & 38,6 & 7,9 & 598 \\
\hline $\begin{array}{l}\text { A szociális munkás munkája a gyakor- } \\
\text { latban „túzoltás”, amibe nem fér bele a } \\
\text { szegénység elleni küzdelem. }\end{array}$ & 4,5 & 23,7 & 39,7 & 32 & 594 \\
\hline \multicolumn{6}{|l|}{ Akadályok, korlátok } \\
\hline $\begin{array}{l}\text { A szegénység kultúrája akadályozza a } \\
\text { szociális szakembert, hogy a családok } \\
\text { szegénységén enyhíthessen. }\end{array}$ & 8,5 & 32 & 48,3 & 11,2 & 588 \\
\hline $\begin{array}{l}\text { A romák kultúrája akadályozza a szociá- } \\
\text { lis szakembert, hogy a családok szegény- } \\
\text { ségén enyhíthessen. }\end{array}$ & 11,5 & 27,6 & 43 & 17,9 & 591 \\
\hline
\end{tabular}

Forrás: Saját szerkesztés 


\section{TEMATIKUS TANULMÁNYOK - Társadalmi mobilitás és segítői tevékenység}

2. táblázat. „A szociális munkásnak van szerepe a családok szegénységének enyhítésében” állítással való egyetértés a szociális munkás szociális problémákban való személyes érintettsége függvényében (\%)

\begin{tabular}{|l|c|c|c|c|c|}
\hline \multirow{2}{*}{ Érintettség } & \multicolumn{4}{|c|}{$\begin{array}{c}\text { A szociális munkásnak } \\
\text { van szerepe a családok szegénységének enyhítésében }\end{array}$} & \multirow{2}{*}{ N } \\
\cline { 2 - 5 } & $\begin{array}{c}\text { Egyáltalán } \\
\text { nem ért egyet }\end{array}$ & $\begin{array}{c}\text { Inkább } \\
\text { nem ért egyet }\end{array}$ & $\begin{array}{c}\text { Inkább } \\
\text { egyetért }\end{array}$ & $\begin{array}{c}\text { Teljesen } \\
\text { egyetért }\end{array}$ & \\
\hline Volt & 2,2 & 20,8 & 53,2 & 23,8 & 231 \\
\hline Nem volt & 5,7 & 26,2 & 51,6 & 16,5 & 351 \\
\hline Összesen & 4,3 & 24,1 & 52,2 & 19,4 & 582 \\
\hline
\end{tabular}

Forrás: Saját szerkesztés

3. táblázat. „A szociális munkásnak van szerepe a családok szegénységének enyhítésében” állítással való egyetértés településtípus szerint (\%)

\begin{tabular}{|l|c|c|c|c|c|}
\hline \multirow{2}{*}{ Településtípus } & \multicolumn{4}{|c|}{$\begin{array}{c}\text { A szociális munkásnak } \\
\text { van szerepe a családok szegénységének enyhítésében }\end{array}$} & \multirow{2}{*}{ N } \\
\cline { 2 - 5 } & $\begin{array}{c}\text { Egyáltalán } \\
\text { nem ért egyet }\end{array}$ & $\begin{array}{c}\text { Inkább } \\
\text { nem ért egyet }\end{array}$ & $\begin{array}{c}\text { Inkább egyet- } \\
\text { ért }\end{array}$ & $\begin{array}{c}\text { Teljesen } \\
\text { egyetért }\end{array}$ & \\
\hline Főváros & 1,4 & 25,4 & 53,5 & 19,7 & 71 \\
\hline Város & 5,1 & 20,6 & 53,7 & 20,6 & 311 \\
\hline Falu & 4,6 & 29,6 & 49,5 & 16,2 & 216 \\
\hline Összesen & 4,5 & 24,4 & 52,2 & 18,9 & 598 \\
\hline
\end{tabular}

Forrás: Saját szerkesztés

4. táblázat. „A szociális munkásnak van szerepe a családok szegénységének enyhítésében” állítással való egyetértés az ellátási terület társadalmi összetétele szerint (\%)

\begin{tabular}{|c|c|c|c|c|c|}
\hline \multirow{2}{*}{$\begin{array}{l}\text { Sok jól szituált } \\
\text { család él itt }\end{array}$} & \multicolumn{4}{|c|}{$\begin{array}{c}\text { A szociális munkásnak } \\
\text { van szerepe a családok szegénységének enyhítésében }\end{array}$} & \multirow{2}{*}{$\mathrm{N}$} \\
\hline & $\begin{array}{c}\text { Egyáltalán } \\
\text { nem ért egyet }\end{array}$ & $\begin{array}{c}\text { Inkább } \\
\text { nem ért egyet }\end{array}$ & $\begin{array}{l}\text { Inkább } \\
\text { egyetért }\end{array}$ & $\begin{array}{l}\text { Teljesen } \\
\text { egyetért }\end{array}$ & \\
\hline Egyáltalán nem igaz & 7,0 & 24,4 & 50,0 & 18,6 & 86 \\
\hline Inkább nem igaz & 5,6 & 25,7 & 50,6 & 18,1 & 249 \\
\hline Inkább igaz & 1,6 & 26,2 & 53,5 & 18,7 & 187 \\
\hline Teljesen igaz & 4,3 & 14,3 & 57,1 & 24,3 & 70 \\
\hline Összesen & 4,4 & 24,3 & 52,2 & 19,1 & 592 \\
\hline
\end{tabular}

Forrás: Saját szerkesztés 
www. metszetek.unideb.hu

\section{TEMATIKUS TANULMÁNYOK - Társadalmi mobilitás és segítői tevékenység}

5. táblázat. „A szociális munkásnak nincs joga, hogy normákat közvetítsen a szegény családok felé" állítással való egyetértés a szociális problémákban való személyes érintettség függvényében (\%)

\begin{tabular}{|l|c|c|c|c|c|}
\hline \multirow{2}{*}{ Érintettség } & \multicolumn{4}{|c|}{ A szociális munkásnak nincs joga, } & \multirow{2}{*}{ Nogy normákat közvetítsen a szegény családok felé } \\
\cline { 2 - 5 } & $\begin{array}{c}\text { Egyáltalán } \\
\text { nem ért egyet }\end{array}$ & $\begin{array}{c}\text { Inkább } \\
\text { nem ért egyet }\end{array}$ & $\begin{array}{c}\text { Inkább egyet- } \\
\text { ért }\end{array}$ & $\begin{array}{c}\text { Teljesen } \\
\text { egyetért }\end{array}$ & \\
\hline Volt & 39,0 & 37,3 & 16,7 & 7,0 & 228 \\
\hline Nem volt & 31,1 & 36,6 & 25,6 & 6,6 & 347 \\
\hline Összesen & 34,3 & 36,9 & 22,1 & 6,8 & 575 \\
\hline
\end{tabular}

Forrás: Saját szerkesztés

6. táblázat. „A szociális munkásnak nincs joga, hogy normákat közvetítsen a szegény családok felé" állítással való egyetértés az ellátási terület társadalmi összetétele

(súlyosan szegény családok előfordulása) szerint (\%)

\begin{tabular}{|l|c|c|c|c|c|}
\hline \multirow{2}{*}{$\begin{array}{c}\text { Sok súlyos } \\
\text { szegénységben élő } \\
\text { család él itt }\end{array}$} & \multicolumn{4}{|c|}{$\begin{array}{c}\text { A szociális munkásnak nincs joga, } \\
\text { hogy normákat közvetítsen a szegény családok felé }\end{array}$} & \multirow{2}{*}{ N } \\
\cline { 2 - 5 } & $\begin{array}{c}\text { Egyáltalán } \\
\text { nem ért egyet }\end{array}$ & $\begin{array}{c}\text { Inkább } \\
\text { nem ért egyet }\end{array}$ & $\begin{array}{c}\text { Inkább } \\
\text { egyetért }\end{array}$ & $\begin{array}{c}\text { Teljesen } \\
\text { egyetért }\end{array}$ & \\
\hline $\begin{array}{l}\text { Egyáltalán } \\
\text { nem igaz }\end{array}$ & 52,5 & 25,0 & 20,0 & 2,5 & 40 \\
\hline Inkább nem igaz & 36,6 & 38,2 & 17,6 & 7,6 & 131 \\
\hline Inkább igaz & 31,8 & 39,4 & 22,0 & 6,8 & 236 \\
\hline Teljesen igaz & 31,7 & 36,6 & 25,1 & 6,6 & 183 \\
\hline Összesen & 34,2 & 37,3 & 21,9 & 6,6 & 590 \\
\hline
\end{tabular}

Forrás: Saját szerkesztés

\section{LEHETŐSÉGEK, ESZKÖZÖK}

A kérdőíves felmérésben arról is kérdeztük a családsegítőket, mennyire látják úgy, hogy a szociális munkásnak a szegénység elleni küzdelemhez rendelkezésére állnak a szükséges eszközök. Itt nem a válaszadó munkavégzésének konkrét körülményei érdekeltek minket, hanem hogy általában adottak-e a feltételek egy szegénységtudatos szociális munkához. A kérdés megosztónak bizonyult: a válaszadóknak csak alig fele $(46,5 \%)$ ért egyet azzal, hogy a szakmának megvannak az eszközei arra, hogy a családok szegénység elleni küzdelmét segítse (lásd 1. táblázat). Ezzel összefüggésben egy olyan állítást is tartalmazott a kérdőív, hogy „a szociális munkás munkája a gyakorlatban 'tűzoltás', melybe nem fér bele a szegénység elleni küzdelem”. Ezzel a 


\section{TEMATIKUS TANULMÁNYOK - Társadalmi mobilitás és segítői tevékenység}

válaszadók 71,7\%-a értett egyet. Szembeszökő ugyanakkor, hogy az állítást elutasítók csoportján belül is mindössze $4,5 \%$ volt azoknak az aránya, akik az 'egyáltalán nem ért egyet' választ adták.

Felvetődik a kérdés, hogy a szegénység mérséklésének lehetőségeiről másként vélekednek-e a válaszadók a különböző egyéni és települési szintű ismérvek függvényében. Elemzéseink azt mutatják, hogy a családsegítők egyéni szintű jellemzői nincsenek hatással arra, hogy milyennek ítélik meg a szegénységet csökkentő eszközök rendelkezésre állását, ami megfelel a várakozásainknak. Arra számíthatnánk ugyanis, hogy a szegénység elleni küzdelemhez a jobb helyzetben lévő településeken inkább megvannak a szükséges eszközök, mint a hátrányosabb helyzetúeken.

A különböző típusú településeken dolgozó szociális szakemberek vonatkozó válaszai között nincsenek különbségek. Megfigyelhető viszont, hogy az ellátási területük társadalmi összetételére vonatkozó percepcióik markáns összefüggést mutatnak azzal, hogy milyennek ítélik a szegénység mérséklésének lehetőségét. Eredményeink szerint, ahol sok jól szituált család él, ott a családsegítők lényegesen nagyobb arányban gondolják, hogy a szakmának rendelkezésére állnak a szegénység enyhítéséhez szükséges eszközök, mint a kevésbé módos környékeken (lásd 7. táblázat). Egyúttal kevésbé fogadják el azt az állítást, hogy a szociális munka a gyakorlatban „tűzoltás” lenne, amelybe nem fér bele a szegénység elleni küzdelem (lásd 8. táblázat).

Nem mutatható ki szignifikáns kapcsolat a mélyszegény és a roma családok nagy előfordulása és a szegénység leküzdéséhez szükséges eszközök meglétére vonatkozó vélemények között. Nem állíthatjuk tehát, hogy azok a szociális munkások, akik a mélyszegény és a roma családok nagy számáról számolnak be, kevésbé érzik magukat ilyen eszközök birtokában, mint a többiek. Az ugyanakkor világosan látszik, hogy azok a segítők, akik a mélyszegény és a roma családok nagyszámú jelenlétét észlelik saját ellátási területükön, azok inkább tartják napi tevékenységüket „tűzoltásnak”, mint azok a társaik, akik nem ilyen környéken dolgoznak (lásd 9. és 10. táblázat).

7. táblázat. „A szociális munkásnak megvannak az eszközei arra, hogy a családok szegénység elleni küzdelmét segítse" állítással való egyetértés az ellátási terület társadalmi összetétele

(jól szituált családok előfordulása) szerint (\%)

\begin{tabular}{|l|c|c|c|c|c|}
\hline \multirow{2}{*}{$\begin{array}{c}\text { Sok jól szituált } \\
\text { család él itt }\end{array}$} & \multicolumn{2}{|c|}{$\begin{array}{c}\text { A szociális munkásnak megvannak az eszközei arra, } \\
\text { hogy a családok szegénység elleni küzdelmét segítse }\end{array}$} & \multirow{2}{*}{$\mathrm{N}$} \\
\cline { 2 - 5 } & $\begin{array}{c}\text { Egyáltalán nem } \\
\text { ért egyet }\end{array}$ & $\begin{array}{c}\text { Inkább } \\
\text { nem ért egyet }\end{array}$ & $\begin{array}{c}\text { Inkább } \\
\text { egyetért }\end{array}$ & $\begin{array}{c}\text { Teljesen } \\
\text { egyetért }\end{array}$ & \\
\hline Egyáltalán nem igaz & 25,6 & 38,4 & 30,2 & 5,8 & 86 \\
\hline Inkább nem igaz & 18,1 & 41,0 & 34,1 & 6,8 & 249 \\
\hline Inkább igaz & 12,8 & 36,4 & 43,3 & 7,5 & 187 \\
\hline Teljesen igaz & 5,7 & 27,1 & 51,4 & 15,7 & 70 \\
\hline Összesen & 16,0 & 37,5 & 38,5 & 7,9 & 592 \\
\hline
\end{tabular}

Forrás: Saját szerkesztés 
www. metszetek.unideb.hu

\section{TEMATIKUS TANULMÁNYOK - Társadalmi mobilitás és segítői tevékenység}

8. táblázat. „A szociális munkás munkája a gyakorlatban »tűzoltás «, amibe nem fér bele a szegénység elleni küzdelem" állítással való egyetértés az ellátási terület társadalmi összetétele (jól szituált családok előfordulása) szerint (\%)

\begin{tabular}{|c|c|c|c|c|c|}
\hline \multirow{2}{*}{$\begin{array}{l}\text { Sok jól szituált } \\
\text { család él itt }\end{array}$} & \multicolumn{4}{|c|}{$\begin{array}{l}\text { A szociális munkás munkája a gyakorlatban „túzoltás”, } \\
\text { amibe nem fér bele a szegénység elleni küzdelem }\end{array}$} & \multirow{2}{*}{$\mathrm{N}$} \\
\hline & $\begin{array}{l}\text { Egyáltalán } \\
\text { nem ért egyet }\end{array}$ & $\begin{array}{l}\text { Inkább } \\
\text { nem ért egyet }\end{array}$ & $\begin{array}{l}\text { Inkább } \\
\text { egyetért }\end{array}$ & $\begin{array}{l}\text { Teljesen } \\
\text { egyetért }\end{array}$ & \\
\hline Egyáltalán nem igaz & 5,8 & 14,0 & 37,2 & 43,0 & 86 \\
\hline Inkább nem igaz & 4,9 & 18,2 & 40,9 & 36,0 & 247 \\
\hline Inkább igaz & 3,8 & 32,3 & 43,0 & 21,0 & 186 \\
\hline Teljesen igaz & 4,3 & 33,3 & 27,5 & 34,8 & 69 \\
\hline Összesen & 4,6 & 23,8 & 39,5 & 32,1 & 588 \\
\hline
\end{tabular}

Forrás: Saját szerkesztés

9. táblázat. „A szociális munkás munkája a gyakorlatban »tűzoltás «, amibe nem fér bele a szegénység elleni küzdelem" állítással való egyetértés az ellátási terület társadalmi összetétele (súlyosan szegény családok előfordulása) szerint (\%)

\begin{tabular}{|l|c|c|c|c|c|}
\hline \multirow{2}{*}{$\begin{array}{c}\text { Sok súlyosan szegény } \\
\text { család él itt }\end{array}$} & \multicolumn{4}{|c|}{$\begin{array}{c}\text { A szociális munkás munkája a gyakorlatban „túzoltás”, } \\
\text { amibe nem fér bele a szegénység elleni küzdelem }\end{array}$} & \multirow{2}{*}{ N } \\
\cline { 2 - 5 } & $\begin{array}{c}\text { Egyáltalán } \\
\text { nem ért egyet }\end{array}$ & $\begin{array}{c}\text { Inkább } \\
\text { nem ért egyet }\end{array}$ & $\begin{array}{c}\text { Inkább } \\
\text { egyetért }\end{array}$ & $\begin{array}{c}\text { Teljesen } \\
\text { egyetért }\end{array}$ & \\
\hline Egyáltalán nem igaz & 12,2 & 29,3 & 46,3 & 12,2 & 41 \\
\hline Inkább nem igaz & 3,8 & 28,0 & 38,6 & 29,5 & 132 \\
\hline Inkább igaz & 5,1 & 24,3 & 42,1 & 28,5 & 235 \\
\hline Teljesen igaz & 2,7 & 18,9 & 35,7 & 42,7 & 185 \\
\hline Összesen & 4,6 & 23,8 & 39,6 & 32,0 & 593 \\
\hline
\end{tabular}

Forrás: Saját szerkesztés 


\section{TEMATIKUS TANULMÁNYOK - Társadalmi mobilitás és segítői tevékenység}

10. táblázat. „A szociális munkás munkája a gyakorlatban »tűzoltás«, amibe nem fér bele a szegénység elleni küzdelem" állítással való egyetértés az ellátási terület társadalmi összetétele (roma családok előfordulása) szerint (\%)

\begin{tabular}{|l|c|c|c|c|c|}
\hline \multirow{2}{*}{ Sok roma család él itt } & \multicolumn{4}{|c|}{$\begin{array}{c}\text { A szociális munkás munkája a gyakorlatban „tűzoltás”, } \\
\text { amibe nem fér bele a szegénység elleni küzdelem }\end{array}$} & \multirow{2}{*}{ N } \\
\cline { 2 - 5 } & $\begin{array}{c}\text { Egyáltalán } \\
\text { nem ért egyet }\end{array}$ & $\begin{array}{c}\text { Inkább } \\
\text { nem ért egyet }\end{array}$ & $\begin{array}{c}\text { Inkább } \\
\text { egyetért }\end{array}$ & $\begin{array}{c}\text { Teljesen } \\
\text { egyetért }\end{array}$ & \\
\hline Egyáltalán nem igaz & 10,7 & 23,2 & 37,5 & 28,6 & 56 \\
\hline Inkább nem igaz & 6,5 & 27,1 & 37,4 & 29,0 & 107 \\
\hline Inkább igaz & 3,1 & 26,9 & 44,4 & 25,6 & 223 \\
\hline Teljesen igaz & 3,4 & 18,9 & 35,9 & 41,7 & 206 \\
\hline Összesen & 4,6 & 23,8 & 39,5 & 32,1 & 592 \\
\hline
\end{tabular}

Forrás: Saját szerkesztés

\section{AKADÁLYOK, KORLÁTOK}

A kérdőív két kérdést is tartalmazott arra vonatkozóan, hogy milyen tényezők korlátozhatják a szociális munkások lehetőségeit, hogy a családok szegénységén enyhítsenek. Az egyik ilyen azt az állítást fogalmazta meg, hogy „a szegénység kultúrája akadályozza a szociális szakembert, hogy a családok szegénységén enyhítsen”, míg a másik kérdésben ugyanez szerepelt a romák kultúrájára vonatkozóan.

Adataink szerint a szociális szakemberek hattizede ért egyet azzal, hogy a szegénység kultúrája akadályozza a szociális munkást, hogy a családok szegénységén enyhíthessen. Hasonló arányban (60,9\%) jelezték ezt a válaszadók a romák kultúrájával összefüggésben. Megjegyzendő, hogy ez utóbbinál jelentősebb az állítással teljesen egyetértők aránya, mint az előbbinél (lásd 1. táblázat).

Ezúttal is megvizsgáltuk, hogy a válaszadók egyéni jellemzői mennyiben magyarázhatják a szegénység enyhítését akadályozó tényezőkkel kapcsolatos vélekedéseiket. A szokásos szociodemográfiai változók közül sem a nem, sem pedig az életkor esetében nem találtunk szignifikáns összefüggést. Ugyanakkor az látszik, hogy az iskolai háttér és a szociális munka terén szerzett tapasztalat befolyásolja a vélekedéseket. Eredményeink szerint - és várakozásainknak megfelelően - a szociális munkás (vagy ahhoz közeli) diplomával rendelkezők - az ettől eltérő iskolai végzettségűekhez képest - valamivel kevésbé hajlanak arra, hogy a romák kultúráját hátráltató tényezőként lássák a szegénység elleni küzdelemben (az összefüggés 0,1-es szinten szignifikáns) (lásd 11. táblázat). A diploma típusa ugyanakkor nincs hatással a szegénység kultúrájával kapcsolatos vélekedésekre. 


\section{TEMATIKUS TANULMÁNYOK - Társadalmi mobilitás és segítői tevékenység}

A munkatapasztalat ezzel szemben a szegénység kultúrájára vonatkozó nézetekkel mutat összefüggést: minél több tapasztalattal bír egy családsegítő, annál kevésbé hajlamos a szegénység kultúráját a szegénység enyhítését akadályozó tényezőként felfogni (lásd 12. táblázat). Adataink szerint a jelentős, több mint 10 éves tapasztalattal rendelkező szociális munkások különülnek el leginkább az ennél kevésbé rutinos kollégáiktól. Érdekes azonban, hogy a több tapasztalatnak a romák kultúrájával összefüggésben nincs ilyen hatása.

A szociális szakemberek attitúdje nem független annak a településnek a jellemzőitől sem, ahol tevékenységüket végzik. A fővárosban dolgozó szakemberek valamivel kevésbé hajlamosak elfogadni, hogy a szegénység kultúrája akadályozó tényező a szegénység enyhítésében, mint a más városban, vagy még inkább a falvakban dolgozó társaik (0,1-es szignifikanciaszint mellett) (lásd 13. táblázat). Kifejezetten markáns különbség látszik a településtípusok között a romák kultúrájával összefüggésben: míg a fővárosban dolgozó szakemberek többsége (56,5\%) visszautasítja, hogy a romák kultúrája hátráltató tényező a szegénység enyhítésében, addig a városiak és a falusiak többsége (60,1 és 67,8\%) éppen, hogy egyetért vele (lásd 14. táblázat).

Emellett az is megállapítható, hogy a szociális munkások vélekedése függ az általuk észlelt társadalmi kontextustól. A legkevésbé a jól szituált családok nagyszámú jelenlétével jellemezhető ellátási területek esetében találtunk szignifikáns (és jól értelmezhető) összefüggést. Ahol viszont sok a súlyos szegénységben élő család, ott a segítő szakemberek jobban hajlanak arra, hogy akadályt lássanak a szegénység kultúrájában, csakúgy, mint a romák kultúrájában (lásd 15. és 16. táblázat). Ugyanez a megállapítás áll a roma családok (észlelt) nagyszámú jelenléte esetében is. Azaz az látszik, hogy ha a súlyosan szegény és/vagy roma családok nagy száma megváltoztathatja a szociális szakemberek attitűdjét, és fogékonyabbá teheti őket az individualisztikus szegénységmagyarázatokra.

11. táblázat. „A romák kultúrája akadályozza a szociális szakembert, hogy a szegénységükön enyhíthessen” állítással való egyetértés a szociális munkás iskolai végzettsége szerint (\%)

\begin{tabular}{|l|c|c|c|c|c|}
\hline \multirow{2}{*}{$\begin{array}{c}\text { Szociális munkás } \\
\text { vagy kapcsolódó } \\
\text { diploma }\end{array}$} & \multicolumn{4}{|c|}{$\begin{array}{c}\text { A romák kultúrája akadályozza a szociális szakembert, } \\
\text { hogy a szegénységükön enyhíthessen }\end{array}$} & \multirow{2}{*}{ N } \\
\cline { 2 - 5 } & $\begin{array}{c}\text { Egyáltalán } \\
\text { nem ért egyet }\end{array}$ & $\begin{array}{c}\text { Inkább } \\
\text { nem ért egyet }\end{array}$ & $\begin{array}{c}\text { Inkább } \\
\text { egyetért }\end{array}$ & $\begin{array}{c}\text { Teljesen } \\
\text { egyetért }\end{array}$ & \\
\hline Nincs & 10,6 & 23,0 & 46,9 & 19,5 & 226 \\
\hline Van & 12,1 & 30,4 & 40,5 & 17,0 & 365 \\
\hline Összesen & 11,5 & 27,6 & 43,0 & 17,9 & 591 \\
\hline
\end{tabular}

Forrás: Saját szerkesztés 
www. metszetek.unideb.hu

\section{TEMATIKUS TANULMÁNYOK - Társadalmi mobilitás és segítői tevékenység}

12. táblázat. „A szegénység kultúrája akadályozza a szociális szakembert, hogy a szegénységükön enyhíthessen" állítással való egyetértés a szociális munkás iskolai végzettsége szerint (\%)

\begin{tabular}{|l|c|c|c|c|c|}
\hline \multirow{2}{*}{ Munkatapasztalat } & \multicolumn{4}{|c|}{$\begin{array}{c}\text { A szegénység kultúrája akadályozza a szociális szakembert, } \\
\text { hogy a szegénységükön enyhíthessen }\end{array}$} & \multirow{2}{*}{ N } \\
\cline { 2 - 5 } & $\begin{array}{c}\text { Egyáltalán } \\
\text { nem ért egyet }\end{array}$ & $\begin{array}{c}\text { Inkább } \\
\text { nem ért egyet }\end{array}$ & $\begin{array}{c}\text { Inkább } \\
\text { egyetért }\end{array}$ & $\begin{array}{c}\text { Teljesen } \\
\text { egyetért }\end{array}$ & \\
\hline Nincs & 7,1 & 30,4 & 46,4 & 16,1 & 112 \\
\hline 1-5 év & 6,8 & 30,8 & 52,1 & 10,3 & 117 \\
\hline 6-10 év & 5,6 & 32,4 & 50,9 & 11,1 & 108 \\
\hline Több mint 10 év & 11,5 & 33,7 & 45,3 & 9,5 & 243 \\
\hline Összesen & 8,6 & 32,2 & 47,9 & 11,2 & 580 \\
\hline
\end{tabular}

Forrás: Saját szerkesztés

13. táblázat. „A szegénység kultúrája akadályozza a szociális szakembert, hogy a szegénységükön enyhíthessen" állítással való egyetértés a szociális munkás iskolai végzettsége szerint (\%)

\begin{tabular}{|l|c|c|c|c|c|}
\hline \multirow{2}{*}{ Településtípus } & \multicolumn{4}{|c|}{$\begin{array}{c}\text { A szegénység kultúrája akadályozza a szociális szakembert, } \\
\text { hogy a szegénységükön enyhíthessen }\end{array}$} & \multirow{2}{*}{ N } \\
\cline { 2 - 5 } & $\begin{array}{c}\text { Egyáltalán } \\
\text { nem ért egyet }\end{array}$ & $\begin{array}{c}\text { Inkább } \\
\text { nem ért egyet }\end{array}$ & $\begin{array}{c}\text { Inkább } \\
\text { egyetért }\end{array}$ & $\begin{array}{c}\text { Teljesen } \\
\text { egyetért }\end{array}$ & \\
\hline Főváros & 11,4 & 32,9 & 51,4 & 4,3 & 70 \\
\hline Város & 7,9 & 34,1 & 46,6 & 11,5 & 305 \\
\hline Falu & 8,5 & 28,6 & 49,8 & 13,1 & 213 \\
\hline Összesen & 8,5 & 32,0 & 48,3 & 11,2 & 588 \\
\hline
\end{tabular}

Forrás: Saját szerkesztés

14. táblázat. „A romák kultúrája akadályozza a szociális szakembert, hogy a szegénységükön enyhíthessen" állítással való egyetértés a szociális munkás iskolai végzettsége szerint (\%)

\begin{tabular}{|l|c|c|c|c|c|}
\hline \multirow{2}{*}{ Településtípus } & \multicolumn{4}{|c|}{$\begin{array}{c}\text { A romák kultúrája akadályozza a szociális szakembert, } \\
\text { hogy a szegénységükön enyhíthessen }\end{array}$} & \multirow{2}{*}{ N } \\
\cline { 2 - 5 } & $\begin{array}{c}\text { Egyáltalán } \\
\text { nem ért egyet }\end{array}$ & $\begin{array}{c}\text { Inkább } \\
\text { nem ért egyet }\end{array}$ & $\begin{array}{c}\text { Inkább } \\
\text { egyetért }\end{array}$ & $\begin{array}{c}\text { Teljesen } \\
\text { egyetért }\end{array}$ & \\
\hline Főváros & 18,8 & 37,7 & 39,1 & 4,3 & 69 \\
\hline Város & 12,3 & 27,6 & 39,3 & 20,8 & 308 \\
\hline Falu & 7,9 & 24,3 & 49,5 & 18,2 & 214 \\
\hline Összesen & 11,5 & 27,6 & 43,0 & 17,9 & 591 \\
\hline
\end{tabular}

Forrás: Saját szerkesztés 
www. metszetek.unideb.hu

\section{TEMATIKUS TANULMÁNYOK - Társadalmi mobilitás és segítői tevékenység}

15. táblázat. „A szegénység kultúrája akadályozza a szociális szakembert, hogy a szegénységükön enyhíthessen" állítással való egyetértés az ellátási terület társadalmi összetétele (súlyosan szegény családok előfordulása) szerint (\%)

\begin{tabular}{|l|c|c|c|c|c|}
\hline \multirow{2}{*}{$\begin{array}{c}\text { Sok súlyosan szegény } \\
\text { család él itt }\end{array}$} & \multicolumn{4}{|c|}{$\begin{array}{c}\text { A szegénység kultúrája akadályozza a szociális szakembert, } \\
\text { hogy a szegénységükön enyhíthessen }\end{array}$} & \multirow{2}{*}{ N } \\
\cline { 2 - 5 } & $\begin{array}{c}\text { Egyáltalán } \\
\text { nem ért egyet }\end{array}$ & $\begin{array}{c}\text { Inkább } \\
\text { nem ért egyet }\end{array}$ & $\begin{array}{c}\text { Inkább } \\
\text { egyetért }\end{array}$ & $\begin{array}{c}\text { Teljesen } \\
\text { egyetért }\end{array}$ & \\
\hline Egyáltalán nem igaz & 12,2 & 41,5 & 36,6 & 9,8 & 41 \\
\hline Inkább nem igaz & 11,5 & 30,0 & 50,8 & 7,7 & 130 \\
\hline Inkább igaz & 6,9 & 30,5 & 53,6 & 9,0 & 233 \\
\hline Teljesen igaz & 7,1 & 33,3 & 42,6 & 16,9 & 183 \\
\hline Összesen & 8,3 & 32,0 & 48,4 & 11,2 & 587 \\
\hline
\end{tabular}

Forrás: Saját szerkesztés

16. táblázat. „A romák kultúrája akadályozza a szociális szakembert, hogy a szegénységükön enyhíthessen" állítással való egyetértés az ellátási terület társadalmi összetétele (roma családok előfordulása) szerint (\%)

\begin{tabular}{|l|c|c|c|c|c|}
\hline \multirow{2}{*}{ Sok roma család él itt } & \multicolumn{4}{|c|}{$\begin{array}{c}\text { A romák kultúrája akadályozza a szociális szakembert, } \\
\text { hogy a szegénységükön enyhíthessen }\end{array}$} & \multirow{2}{*}{ N } \\
\cline { 2 - 5 } & $\begin{array}{c}\text { Egyáltalán } \\
\text { nem ért egyet }\end{array}$ & $\begin{array}{c}\text { Inkább } \\
\text { nem ért egyet }\end{array}$ & $\begin{array}{c}\text { Inkább } \\
\text { egyetért }\end{array}$ & $\begin{array}{c}\text { Teljesen } \\
\text { egyetért }\end{array}$ & \\
\hline Egyáltalán nem igaz & 15,1 & 37,7 & 37,7 & 9,4 & 53 \\
\hline Inkább nem igaz & 12,8 & 35,8 & 37,6 & 13,8 & 109 \\
\hline Inkább igaz & 9,0 & 26,9 & 47,5 & 16,6 & 223 \\
\hline Teljesen igaz & 12,6 & 21,4 & 42,2 & 23,8 & 206 \\
\hline Összesen & 11,5 & 27,6 & 43,0 & 17,9 & 591 \\
\hline
\end{tabular}

Forrás: Saját szerkesztés 


\section{TEMATIKUS TANULMÁNYOK - Társadalmi mobilitás és segítői tevékenység}

\section{ÖSSZEFÜGGÉS A SZEREPFELFOGÁS ÉS AZ ESZKÖZÖKKEL, LEHETŐSÉGEKKEL KAPCSOLATOS VÉLEKEDÉSEK KÖZÖTT}

Végül azt is körüljártuk, hogyan függenek össze egymással a kérdőívnek a szociális munka szerepével és e szerep betöltésének lehetőségeivel kapcsolatos kérdéseire adott válaszok.

Elemzéseink szignifikáns összefüggést jeleznek a szociális munkás szerepkörével kapcsolatos és a jogait illető vélemények között. Azok, akik szerint a szociális munkásoknak feladata a szegénység enyhítése, nagyobb arányban formálnak jogot a normák közvetítésére (lásd 17. táblázat). Érdekes azonban, hogy a normák közvetítéséhez való jogot még azok is kétharmad részben hajlamosak elismerni, akik szerint a szociális munkásnak nincs szerepe a szegénységgel kapcsolatosan.

Szignifikáns és erős összefüggést mutattunk ki a szociális munkások szegénységgel kapcsolatos szerepfelfogása és aközött, hogy mit gondolnak a szegénység enyhítéséhez szükséges eszközök rendelkezésére állásáról. Azt találtuk, hogy akik szerint a szociális munkásnak van szerepe a szegénység enyhítésében, azok számottevően nagyobb arányban vélik úgy, hogy ehhez eszközeik is vannak, mint azok, akik nem osztják ezt a pozitív szerepfelfogást (lásd 18. táblázat). De hangsúlyozandó, hogy még a válaszadók abban a csoportjában is, amelyik szerint a szociális munkásnak van ilyen szerepe, csak valamivel több mint minden második kérdezett véli úgy, hogy ehhez adottak az eszközök is.

Ezzel összhangban azt találtuk továbbá, hogy akik szerint a szociális munkásnak van szerepe a szegénység enyhítésében, azok kevésbé tartják úgy, hogy ez nem fér bele a munkájukba (68,1\% a 80,9\%-kal szemben) (lásd 19. táblázat). Az összefüggések egy lehetséges értelmezése, hogy a praxis is (vissza)hathat a percepcióra. Azaz aki nem látja biztosítva az eszközök rendelkezésre állását, illetve a szerep betöltésének lehetőségét, az hajlamosabb lehet azt gondolni, hogy nem is feladata (nem lehet feladata az adott körülmények között) a szegénység enyhítése.

17. táblázat. A szerepfelfogásra és a normák közvetítéséhez való jogra vonatkozó vélekedések összefüggései (\%)

\begin{tabular}{|c|c|c|c|}
\hline \multirow{2}{*}{$\begin{array}{c}\text { A szociális munkásnak } \\
\text { van szerepe a családok } \\
\text { szegénységének enyhítésében }\end{array}$} & \multicolumn{2}{|c|}{$\begin{array}{l}\text { A szociális munkásnak nincs joga, } \\
\text { hogy normákat közvetítsen a szegény családok felé }\end{array}$} & \multirow{2}{*}{$\mathrm{N}$} \\
\hline & Nem ért egyet & Egyetért & \\
\hline Nem ért egyet & 65,9 & 34,1 & 170 \\
\hline Egyetért & 73,7 & 26,3 & 419 \\
\hline Összesen & 71,5 & 28,5 & 589 \\
\hline
\end{tabular}

Forrás: Saját szerkesztés 
www. metszetek.unideb.hu

\section{TEMATIKUS TANULMÁNYOK - Társadalmi mobilitás és segítői tevékenység}

18. táblázat. A szerepfelfogásra és az eszközök rendelkezésre állására vonatkozó vélekedések összefüggései (\%)

\begin{tabular}{|c|c|c|c|}
\hline \multirow{2}{*}{$\begin{array}{l}\text { A szociális munkásnak } \\
\text { van szerepe a családok } \\
\text { szegénységének enyhítésében }\end{array}$} & \multicolumn{2}{|c|}{$\begin{array}{l}\text { A szociális munkásnak megvannak az } \\
\text { eszközei arra, hogy a családok szegénység elleni } \\
\text { küzdelmét segítse }\end{array}$} & \multirow[t]{2}{*}{$\mathrm{N}$} \\
\hline & Nem ért egyet & Egyetért & \\
\hline Nem ért egyet & 74,6 & 25,4 & 173 \\
\hline Egyetért & 44,9 & 55,1 & 425 \\
\hline Összesen & 53,5 & 46,5 & 598 \\
\hline
\end{tabular}

Forrás: Saját szerkesztés

19. táblázat. A szerepfelfogásra és a gyakorlati megvalósíthatóságra vonatkozó vélekedések összefüggése (\%)

\begin{tabular}{|l|c|c|c|}
\hline \multirow{2}{*}{$\begin{array}{c}\text { A szociális munkásnak van szerepe } \\
\text { a családok szegénységének } \\
\text { enyhítésében }\end{array}$} & $\begin{array}{c}\text { A szociális munkás munkája a gyakorlatban } \\
\text { "tűzoltás", amibe nem fér bele a szegénység elleni } \\
\text { küzdelem }\end{array}$ & \multirow{2}{*}{ N } \\
\cline { 2 - 3 } & Nem ért egyet & Egyetért & \\
\hline Nem ért egyet & 19,1 & 80,9 & 173 \\
\hline Egyetért & 31,9 & 68,1 & 420 \\
\hline Összesen & 28,2 & 71,8 & 593 \\
\hline
\end{tabular}

Forrás: Saját szerkesztés

\section{Összegzés}

A hazai családsegítő szakemberek körében erős konszenzus látszik azzal összefüggésben, hogy a szociális munkának szerepe van a családok szegénységének enyhítésében. Ez annak dacára van így, hogy ugyanilyen mértékben konszenzusos az a nézet, mely szerint a szegénység elleni küzdelem és a családok segítése az alapvető szükségleteik előteremtésében nem ugyanaz a szerep. Előzetes várakozásunknak megfelelően a családsegítők egyéni szociodemográfiai ismérvei mentén nincsenek jelentős különbségek a szakma szegénységgel kapcsolatos szerepét illetően. A szerepfelfogásban akadnak ugyanakkor eltérések a településtípus és - ettől nem teljesen függetlenül - a települések társadalmi összetétele függvényében. A budapesti és városi, illetve a tehetősebb településeken dolgozó családsegítők hajlamosabbak a szegénységgel összefüggő szerepet tulajdonítani a szociális munkásnak, mint a falusi és szegényebb településeken dolgozó kollégáik. Ez összefügghet azzal, hogy az előbbieknek a lehetőségeik is jobbak arra, hogy ezt a szerepet betölthessék, s ez a vélekedéseikre is visszahathat. 


\section{TEMATIKUS TANULMÁNYOK - Társadalmi mobilitás és segítői tevékenység}

Miközben a családsegítők majdnem háromnegyede vallja, hogy a szociális munkásnak szerepe a szegénység mérséklése, addig csak kevesebb mint fele véli úgy, hogy ehhez meg is vannak az eszközei. Ezek az adatok azt sugallják, hogy feszültség van a szakmai szerepfelfogás és a szerep betöltésének lehetőségei (vagy talán még inkább az arra való képtelenség) között. Még jobban érzékelhetővé válik egyfajta szakmai frusztráció, ha a szerepfelfogásról alkotott véleményeket azzal vetjük egybe, hogy mennyire fér bele a mindennapi munkába a szegénység elleni küzdelem. Míg tízből bő hét családsegítő szegénységet illető szerepfelfogása pozitív, addig ugyanennyiből alig három véli úgy, hogy a szociális munkás munkájába a gyakorlatban belefér a szegénység enyhítése.

Azt is láthattuk, hogy a szegénységgel kapcsolatos szerep betöltésének lehetőségeit másként ítélik meg a szociális munkások, attól függően, hogy milyen társadalmi összetételü az ellátási terület, ahol a tevékenységüket végzik. A tehetősebb településeken dolgozók lényegesen nagyobb arányban látják úgy, hogy a szociális munkás birtokában van azoknak az eszközöknek, amik a szegénység leküzdésében segíthetnek, mint azok, akik nem ilyen környéken végzik a munkájukat. Ez feltehetőleg összefügg azzal, hogy a módosabb településeken jobb a családi szociális szolgáltatásokkal való ellátottság, amelyekre a kliensek segítése során támaszkodhatnak.

Az, hogy a szociális munkás mindennapi munkájába mennyire fér bele a szegénység elleni küzdelem, szintén erősen függ attól, hogy milyen társadalmi összetételű az ellátási területe. Azok a szakemberek, akik sok súlyos szegénységben élő, vagy sok roma család jelenlétéről számolnak be az ellátási területükön, inkább hajlanak rá, hogy munkájukat a tűzoltáshoz hasonlítsák, amibe a szegénység leküzdése nem fér bele. Ez összefüggésben állhat azzal, hogy az ilyen hátrányos helyzetű településeken a szegénység gyakori előfordulása további, a család- és gyermekjóléti szolgálatok kompetenciájába tartozó problémák (pl. elhanyagolás, iskolai hiányzás stb.) nagyobb előfordulását hozza magával. Ennél is fontosabb azonban azt hangsúlyozni, hogy a szegény családok meglévő hátrányait ezeken a helyeken tovább súlyosbítja a strukturális képtelenség, vagyis az, hogy az ellátórendszer épp ott tudja a legkevésbé betölteni a feladatát, ahol arra a legnagyobb szükség volna.

A kutatás arra is kitért, hogy milyen tényezők korlátozzák a szociális szakembert abban, hogy a családok szegénységén enyhíthessen. Tízből hat válaszadó szerint jelent akadályt a szegénység kultúrája, s nagyjából ennyiük szerint a romák kultúrája. Éles választóvonal húzódik e tekintetben a fővárosban és a városokban, de még inkább a fővárosban és a falvakban dolgozó családsegítők vélekedése között. Ebben bizonyára fontos szerepe lehet a képzésnek. A módszertani továbbképzés és a szakmai támogatás ugyanis nem egyforma mértékben elérhető a fóvárosban és a kisebb/ távolabbi településen dolgozó családsegítők számára (Rácz 2015). A képzés szerepét húzza alá az is, hogy eredményeink szerint a romák kultúráját kevésbé látják a szegénység elleni küzdelemben akadályozó tényezőnek azok a családsegítők, akik 
www. metszetek.unideb.hu

\section{TEMATIKUS TANULMÁNYOK - Társadalmi mobilitás és segítői tevékenység}

szociális munkás vagy kapcsolódó diplomával rendelkeznek, mint azok, akik egyéb iskolai végzettségűek.

\section{Irodalom}

Axford, N. (2010): Is social exclusion a useful concept in children's services? British Journal of Social Work, 40: 737-754. doi:10.1093/bjsw/bcn121

Bermaoui, J. - Keppens, D. - Stolberg, C. (2012): The 'turn to parenting' in England, France, Germany and the Netherlands. Paper presented at the 'Think Parents!' Conference, The Hague, 10-12 October.

Cantillon, B. (2011): The paradox of the social investment state: Growth, employment and poverty in the Lisbon era. Journal of European Social Policy, 21: 432-449. doi:10.1177/ 0958928711418856

Carlson, J. (2017): 'What can I do'? Child welfare workers' perceptions of what they can do to address poverty. Journal of Children and Poverty, 23(2): 161-176. doi: $10.1080 / 10796126.2017 .1358588$

Clarke, K. (2006): Childhood, parenting and early intervention: A critical examination of the Sure Start national programme. Critical Social Policy, 26: 699-721. doi: $10.1177 / 0261018306068470$

Dowling, M. (1999): Social exclusion, inequality and social work. Social Policy \& Administration, 33: 245-261. doi:10.1111/1467-9515.00149

Duva, J. - S. Metzger (2010): Addressing Poverty as a Major Risk Factor in Child Neglect: Promising Policy and Practice. Protecting Children 25(1): 63-74.

http://childhub.org/sites/default/files/addressing-poverty-as-a-major-riskfactor-in-child.pdf (Utolsó letöltés: 2020. 07. 15.)

Hall, C. - Parton, N. - Peckover, S. - S. White (2010): Child-centric information and communication technology (ICT) and the fragmentation of child welfare practice in England. International Journal of Social Policy, 39: 393-413. doi:10.1017/ S0047279410000012

Heckman, J. (2006): Skill formation and the economics of investing in disadvantaged children. Science, 312: 1900-1902. doi:10.1126/science.1128898

KSH (2016): Gyermekesély - a gyermekvédelmi jelzőrendszer működése, 2014. Statisztikai Tükör, 2016. február 5. https://www.ksh.hu/docs/hun/xftp/stattukor/ gyermekvedelem14.pdf (Utolsó letöltés: 2020. 07. 15.)

Lindsey, D. (2003): The Welfare of Children. New York, Oxford University Press doi:10.1093/acprof:oso/9780195136715.001.0001 


\section{TEMATIKUS TANULMÁNYOK - Társadalmi mobilitás és segítői tevékenység}

Martin, M. - Citrin, A. (2014): Prevent, Protect \& Provide: How child welfare can b-Better support low-income families. Washington, DC., Center for the Study of Social Policy http://childwelfaresparc.org/wp-content/uploads/2014/08/ Prevent-Protect-Provide-Brief.pdf. (utolsó letöltés: 2020. 07. 15.)

McCartan, C. - Morrison, A. - Bunting, L. - Davidson, G. - Mcllroy, J. (2018): Stripping the wallpaper of practice: Empowering social workers to tackle poverty. Social Sciences 7(193): 1-16. doi:10.3390/socsci7100193

Mestrum, F. (2011): Child poverty: A critical perspective. Social Work \& Society, 9: 161-168. https://www.socwork.net/sws/article/view/17/116 (Utolsó letöltés: 2020. 07. 15.)

Mestrum, F. (2013): An emerging new social paradigm for Europe.

http://www.globalsocialjustice.eu/index.php?option=com_content\&view=article\&id=397:an-emerging-newsocial-paradigm-for-europe\&catid=10:research\&Itemid=13 (Utolsó letöltés: 2020. 07.15.)

Morabito, C. - Vandenbroeck, M. - Roose, R. (2013): The greatest of equalisers: A critical review of international organisations views on early childhood care and education. Journal of Social Policy, 42: 451-467. doi:10.1017/ S0047279413000214

Popkewitz, T. S. (2003): Governing the child and pedagogicalization of the parent: A historical excursus into the present. In: Bloch, M. N. - Holmlund, K. - Moqvist, I. - Popkewitz, T. S. (eds.): Governing children, families and education. New York, Palgrave Macmillan, 35-61. doi: https://doi.org/10.1007/978-1-137-08023-3_2

Rácz A. (szerk.) (2015): A gyermekjóléti szolgálatok feladatellátásának értékelő elemzése országos szinten. Budapest, Rubeus Egyesület.

Schiettecat, T. - Roets, G. - Vandenbroeck, M. (2014): Do families in poverty need child and family social work? European Journal of Social Work, 18(5): 647-660. doi: 10.1080/13691457.2014.953916

Staab, S. (2010): Social investment policies in Chile and Latin America: Towards equal opportunities for women and children? Journal of Social Policy, 39: 607626. doi:10.1017/S0047279410000243

Szöllősi G. (2003): A gyermekvédelmi probléma mint társadalmi konstrukció. Esély 14(2): 75-95. 